\title{
1 Synthesis of oxyfunctionalized NSAID metabolites by microbial biocatalysts
}

2 Jan M. Klenk ${ }^{\text {a }}$, Lisa Kontny ${ }^{\mathrm{a} *}$, Bernd A. Nebel ${ }^{\mathrm{a}}$, Bernhard Hauer ${ }^{\mathrm{a}}$ \#

4 anstitute of Biochemistry and Technical Biochemistry, University of Stuttgart,

$5 \quad$ Allmandring 31, 70569 Stuttgart, Germany

6

7 Running Head: NSAID oxyfunctionalization by microbial biocatalysts

9 \#Address correspondence to Bernhard Hauer, bernhard.hauer@itb.uni-stuttgart.de; phone:

10 +49711685 63193; fax: +4971168563196.

11 *Present address: Lisa Kontny, Marabu GmbH, Tamm, Germany.

13 Abbreviations: GC, gas chromatography; HPLC, high-performance liquid

14 chromatography; MS, mass spectrometry; NMR, nuclear magnetic resonance; NSAID,

15 non-steroidal anti-inflammatory drug; PEG, potato-extract-glucose; P450, cytochrome

16 P450 monooxygenase; P450 BM3, cytochrome P450 from Bacillus megaterium; P450

17 RhF, cytochrome P450 from Rhodococcus sp. strain NCIMB 9784. 


\section{Abstract}

19 The synthesis of valuable metabolites and degradation intermediates of drugs, like non-

20 steroidal anti-inflammatory drugs (NSAIDs), are substantially for toxicological and

21 environmental studies, but efficient synthesis strategies and the metabolite availability are

22 still challenging aspects. To overcome these bottlenecks filamentous fungi as microbial

23 biocatalysts were applied. Different NSAIDs like diclofenac, ibuprofen, naproxen and

24 mefenamic acid could be oxyfunctionalized to produce human metabolites in isolated

25 yields of up to $99 \%$ using $1 \mathrm{~g} \mathrm{~L}^{-1}$ of substrate. Thereby the biotransformations using

26 Beauveria bassiana, Clitocybe nebularis or Mucor hiemalis surpass previous reported

27 chemical, microbial and P450-based routes in terms of efficiency. In addition to different

28 hydroxylated compounds of diclofenac, a novel metabolite, 3',4'-dihydroxydiclofenac, has

29 been catalyzed by B. bassiana and the responsible P450s were identified by proteome

30 analysis. The applied filamentous fungi present an interesting alternative, microbial

31 biocatalysts platform for the production of valuable oxyfunctionalized drug metabolites.

\section{Importance}

34 The occurrence of pharmaceutically active compounds, such as diclofenac and its

35 metabolites, in the environment, in particular in aquatic systems, is of increasing concern

36 because of the increased application of drugs. Standards of putative metabolites are

37 therefore necessary for environmental studies. Moreover, pharmaceutical research and

38 development requires assessment of the bioavailability, toxicity and metabolic fate of

39 potential new drugs to ensure its safety for users and the environment. Since most of the

40 reactions in the early pharmacokinetics of drugs are oxyfunctionalizations catalysed by 
$41 \mathrm{P} 450 \mathrm{~s}$, oxyfunctionalized metabolites are of major interest. However, to assess these

42 metabolites chemical synthesis often suffer from multistep reactions, toxic substances,

43 polluting conditions and achieve only low regioselectivity. Biocatalysis can contribute to

44 this by using microbial cell factories. The significance of our research is to complement or

45 even exceed synthetic methods for the production of oxyfunctionalized drug metabolites.

47 Keywords: Biotransformation; Filamentous fungi; Microbial biocatalysts; NSAIDs;

48 Oxyfunctionalized metabolites

\section{$50 \quad$ Introduction}

51 Next to chemical processes, biotechnology routes can play a significant role for the access

52 to pharmaceutically active substances and their metabolites. Metabolites and degradation

53 intermediates can have major environmental implications, which can lead to unwanted side

54 reactions in nature and mammalians. Due to the fact that numerous drug metabolites are

55 detected in higher amounts in different habitats, thus detailed environmental and

56 toxicological studies are necessary. These findings induced that the FDA (Food and Drug

57 Administration) issued guidelines for metabolites in drug testing, setting a limit of $10 \%$ in

$58 \quad 2008$.

59 Approximately $80 \%$ of all reactions in the early pharmacokinetics of drugs (phase I

60 reactions) are P450-catalyzed $(1,2)$. Therefore, oxyfunctionalized metabolites are often

61 major degradation intermediates of potential toxic endogenous and exogenous compounds

62 in mammalians and nature. For further approval of new drugs, knowledge about potential

63 metabolism intermediates and their availability for toxicological studies are obligatory (3- 
64 5). As a very present example, a molecule like diclofenac (1), a widespread non-steroidal 65 anti-inflammatory drug (NSAID), and its already known hydroxylated degradation 66 metabolites 4'- and 5-hydroxydiclofenac ( 2 and 3 ) pose an environmental problem due to 67 their low degradability $(6,7)$. Thereby, the request for particular drug metabolites increases 68 simultaneously with the number of newly developed drugs, to study pharmacokinetic and 69 toxic effects caused by metabolism $(8,9)$. Due to limited availability and often time as well 70 as cost elaborating chemical synthesis routes, the value of drug metabolites can reach up 71 to several hundred dollars per milligram. As mentioned above, the chemical synthesis of 72 human metabolites such as 4'- and 5-hydroxydiclofenac (2 and 3) for toxicological studies

73 is tedious and has only been achieved in low yields linked with high by-product formation

74 (10-12). To complement synthetic methods, microbial processes with heterologous

75 expressed P450s and wild-type organisms have emerged as an valuable alternative to 76 chemical syntheses $(13,14)$.

77 Most of the previous studies focused on heterologous expressed human P450s which can 78 produce the corresponding metabolites detectable in the human body (15). One example is 79 CYP2C9 that was recombinant produced in different hosts and finally used for the 80 production of $468 \mathrm{mg} \mathrm{L}^{-1}$ of 4'-hydroxydiclofenac (2) (14, 16). Furthermore, the low 81 activities and selectivities of the wild type P450 BM3 were improved by directed evolution 82 resulting in variants which led to a significantly enhanced oxidation capability of NSAIDs

83 (17-20). In this context we recently published the scale-up of the self-sufficient P450 RhF 84 (21). The enzyme was heterologous expressed and implemented as whole cell system, 85 whereby 5-hydroxydiclofenac (3) was produced exclusively in high titers of up to $86357 \mathrm{mg} \mathrm{L}^{-1}$. However, high yields with NSAIDs are rather the exception, because often the 
87 product yields obtained with $\mathrm{P} 450$ s or microorganisms are in the lower milligram range

88 (17, 22-26). Therefore, the biotechnological synthesis of such oxyfunctionalized

89 compounds for environmental and toxicological studies remains expandable.

90 Based on our previous hydroxylation experiment studies with diclofenac (1) as substrate,

91 we further extended the biocatalyst platform for NSAID oxyfunctionalizations by a

92 spectrum of available biocatalysts. In this work, we intended to identify new microbial

93 biocatalysts able to catalyze NSAID metabolites and degradation intermediates in high

94 yields, to provide those molecules for further drug development and toxicological studies.

95

96 Materials and Methods

97 Materials

98 The chemicals and media used in this study were obtained from Fluka (Buchs,

99 Switzerland), Sigma-Aldrich (St. Louis, Missouri, USA) Alfa-Aesar (Ward Hill,

100 Massachusetts, USA) and Carl-Roth (Karlsruhe, Germany) in highest available purity

101 degrees. The KOD HS polymerase was from Novagene Inc. (Madison, Wisconsin, USA).

102

103 Isolation of genomic DNA from eukaryotes

104 For the isolation of genomic DNA from eukaryotes, precultures of the various filamentous

105 fungi were cultured on PEG broth (potato-extract-glucose broth) as medium for about

1063 days at $27^{\circ} \mathrm{C}$ and $180 \mathrm{rpm}$. An initial cell lysis was achieved by centrifugation of the

107 cultures, freezing at $-80^{\circ} \mathrm{C}$ for $10 \mathrm{~min}$ and crushing the frozen mycelia with a mortar.

108 Subsequently, the samples were isolated according to the manufacturer's instructions using 
109 the ZR Fungal/Bacterial DNA Microprep ${ }^{\text {TM }}$ kit (Zymo Research Corp., Irvine, California,

110 USA). The elution of the DNA was carried out with $25 \mu \mathrm{LddH}_{2} \mathrm{O}$.

111

112 Polymerase chain reaction (PCR) for the amplification of DNA fragments

113 The PCR was used to selectively amplify DNA fragments of genomic DNA based on the

114 primers ITS4 (5'-TCCTCCGCTTATTGATATGC-3') and ITS5

115 (5'-GGAAGTAAAAGTCGTAACAAGG-3') $\quad$ or LR0R

116 (5'-ACCCGCTGAACTTAAGC-3') and LR5 (5'-TCCTGAGGGAAACTTCG-3') as

117 described by Schoch and coworkers in 2012 (27). For the elongation KOD HS Polymerase

118 was used in $50 \mu \mathrm{L}$ total volume using the components and programs as shown in TABLE

$119 \mathrm{~S} 1$ and S2.

120 The success of the PCR reactions was controlled by an agarose gel and the DNA fragments

121 were then directly isolated (Figure S1). Therefore, the DNA fragments were visualized

122 under UV light (366 nm) and cut out of the agarose gel with a scalpel, weighed and treated

123 with the Zymoclean Gel DNA Recovery Kit (Zymo Research Corp., Irvine, California,

124 USA) according to the manufacturer's instructions. The isolated DNA was subsequently

125 eluted with $20 \mu \mathrm{L}$ ddH2O. For the analysis of the DNA samples, a volume of $20 \mu \mathrm{L}$ and a

126 concentration of $50-70 \mathrm{ng} \mu \mathrm{L}^{-1}$ were used. The sequencing was done by GATC Biotech

127 AG (Konstanz, Germany) using the primers of the PCR amplification.

129 Proteome analysis of Beauveria bassiana

130 For the cell disruption of Beauveria bassiana, liquid cultures were centrifuged and the 131 mycelia subsequently washed with $\mathrm{ddH}_{2} \mathrm{O}$ over a filter paper and dried. In a Petri dish, the 
132 samples were lyophilized (Alpha 2-4 LD plus, Martin Christ Gefriertrocknungsanlagen

$133 \mathrm{GmbH}$, Osterode am Harz, Germany), to rub this later as a first partial disruption with the

134 mortar. 35-50 mg of powder was mixed with an equivalent volume of glass beads (0.1-

$1350.25 \mathrm{~mm})$ and $1 \mathrm{~mL}$ urea buffer (28) (25 mM Tris/HCl pH 6.8, $9 \mathrm{M}$ urea, $1 \%$ SDS, $1 \mathrm{mM}$

136 EDTA, direct before use 0.7 M DTT). Subsequently, the cell disruption samples were

137 heated to $95^{\circ} \mathrm{C}$ for $2 \mathrm{~min}$, shaken for $1 \mathrm{~min}$ by vortexing and heated again at $95^{\circ} \mathrm{C}$ for

1381 min. After separation of the glass beads by short centrifugation, the DNA was sheared

139 by sonication (Branson Sonifier 250 equipped with a microtip: 1/8 "diameter, Danbury,

140 Connecticut, USA, pulse: output 2, duty cycle: $35 \%$ ) for $30 \mathrm{s.}$

141 A 3-day PEG broth preculture was used to inoculate $100 \mathrm{~mL}$ PEG broth with 1/75 volume

142 of preculture. The biotransformations were started after $24 \mathrm{~h}$ incubation with the addition

143 of $0.5 \mathrm{~g} \mathrm{~L}^{-1}$ of the substrates or glucose as a reference. The reactions were stopped after

144 first products were detected (48 h for $(R)$-2-phenoxypropionic acid and $68 \mathrm{~h}$ for diclofenac

145 (1)). The cells were then lysed as described above and the proteins of the samples analyzed

146 and diluted as a whole cell suspension on a 10\% and a 15\% SDS-polyacrylamide gel.

147 The proteome analysis was carried out at the mass spectrometry service unit in Hohenheim

148 (Germany, group of Dr. Pfannstiel) using an ACQUITY nano-UPLC system (Waters

$149 \mathrm{GmbH}$, Milford, USA) directly coupled to a LTQ-Orbitrap XL hybrid mass spectrometer

150 (Thermo Fisher Scientific, Bremen, Germany) with following minor changes as described

151 previously (29). Tryptic digests were separated on a $25 \mathrm{~cm}$ x $75 \mu \mathrm{m}$ x $1.7 \mu \mathrm{m} \mathrm{BEH} 130 \mathrm{C}_{18}$

152 reversed phase column (Waters $\mathrm{GmbH}$ ) with gradient elution performed from $1 \%$ ACN to

$15350 \% \mathrm{ACN}$ in $0.1 \%$ formic acid within $120 \mathrm{~min}$. Identification of the proteins was based on

154 a global NCBI database search applying the MASCOT search algorithm. The mass 
155 spectrometry proteomics data have been deposited to the ProteomeXchange Consortium

156 via the PRIDE (30) partner repository with the dataset identifier PXD009664 and

$157 \quad$ 10.6019/PXD009664.

158

159 Preparative biotransformations

160 The filamentous fungi applied in this work were cultured in PEG broth, in which a better

161 growth could be achieved in comparison to sabouraud medium. On PEG-agar, the hyphae

162 were transferred once a month and incubated at $27^{\circ} \mathrm{C}$ for several days (M. hiemalis: 3 days,

163 B. bassiana: 4 days, C. nebularis: 5 days). B. bassiana used in this work was modified by

164 UV radiation to allow yeast-like growth in liquid culture (31). $50 \mathrm{~mL}$ of PEG broth was

165 once inoculated with a loop tip, whereas M. hiemalis and C. nebularis were inoculated

166 several times with hyphae to slightly disperse and therefore minimize lumpy mycelial

167 growth. The fungi were cultured for 4 days at $27^{\circ} \mathrm{C}$ and $180 \mathrm{rpm}$ and then transferred to

$16850-400 \mathrm{ml}$ main cultures which were inoculated with 1/75 volume (B. bassiana) or with

169 the filtered mycelia (M. hiemalis and C. nebularis) of the preculture. After $24 \mathrm{~h}$ of

170 incubation, the biotransformations were started with $1 \mathrm{~g} \mathrm{~L}^{-1}$ substrate $\left(50 \mathrm{~g} \mathrm{~L}^{-1}\right.$ stock

171 solution in DMSO) or in the case of diclofenac (1) with $0.6 \mathrm{~g} \mathrm{~L}^{-1}$ for $72 \mathrm{~h}$ or $144 \mathrm{~h}$,

172 respectively. At regular intervals, $500 \mu \mathrm{L}$ samples were taken, centrifuged and the

173 supernatant was used for analysis by GC-FID, HPLC-DAD or LC-MS. The

174 biotransformations were carried out in biological duplicates starting from different agar

175 plates.

176

177 
179 Diclofenac (1) and its metabolites were analyzed by HPLC and LC-MS as described

180 elsewhere (21).

\section{GC analytic}

183 Naproxen (6), ibuprofen (8) and mefenamic acid (12) were analyzed by gas

184 chromatography. For this purpose, the samples $(500 \mu \mathrm{L})$ were centrifuged and $250 \mu \mathrm{L}$ of

185 the supernatant initially acidified by $10 \mu \mathrm{L} \mathrm{HCl}$ prior extraction with the same volume of

186 MTBE. The organic phase was then evaporated on a Genevac EZ-2 Plus Evaporator

187 (Ipswich, UK) and resuspended in a mix of 50\% MTBE and 50\% BSTFA + TCMS (99: 1).

188 The derivatization of the samples $(150 \mu \mathrm{L})$ was carried out in $\mathrm{GC}$ vials at $70^{\circ} \mathrm{C}$ for $30 \mathrm{~min}$.

189 GC analysis was performed on a Shimadzu GC-2010 equipped with an AOC-20i

190 autoinjector (Shimadzu, Nakagyo-ku, Japan). The samples were injected with a split of 20

$191\left(1 \mu \mathrm{L}\right.$ injection volume, injector temperature $250^{\circ} \mathrm{C}$, carrier gas $\left.\mathrm{H}_{2}, 30 \mathrm{~cm} \mathrm{~s}^{-1}\right)$ and 192 separated by a DB-5 column (30 m x $0.25 \mathrm{~mm}$ x $0.25 \mu \mathrm{m}$, Agilent Technologies, Santa

193 Clara, California, USA). The analytes were detected by a flame ionization detector (FID,

194 detector temperature $330^{\circ} \mathrm{C}$ ). For $\mathbf{6}$ and $\mathbf{1 2}$ the column temperature was maintained at

$195150^{\circ} \mathrm{C}$ for $1 \mathrm{~min}$, increased to $280^{\circ} \mathrm{C}$ at a rate of $10^{\circ} \mathrm{C} \mathrm{min}{ }^{-1}$ and held for $1 \mathrm{~min}$, raised to

$196320^{\circ} \mathrm{C}$ at a rate of $65^{\circ} \mathrm{C} \min ^{-1}$ and held for $3 \mathrm{~min}$. For $\mathbf{8}$ the column temperature was

197 maintained at $90^{\circ} \mathrm{C}$ for $1 \mathrm{~min}$, increased to $280^{\circ} \mathrm{C}$ at a rate of $12^{\circ} \mathrm{C} \mathrm{min}^{-1}$ and held for $1 \mathrm{~min}$,

198 raised to $320^{\circ} \mathrm{C}$ at a rate of $65^{\circ} \mathrm{C} \mathrm{min}^{-1}$ and held for $3 \mathrm{~min}$.

199 For initial product identification, the samples were run on GC-2010 GC-MS system

200 equipped with Shimadzu GCMS-QP2010 detector and AOC-5000 autoinjector (Shimadzu, 
201 Nakagyo-ku, Japan) and helium as carrier gas (linear velocity $30 \mathrm{~cm} \mathrm{~s}^{-1}$ ). The analytes were

202 separated on a DB-5 column and measured with identical temperature programs for

203 GC-FID analysis. For the recording of the mass spectra, an ionization (EI, Electron

204 Ionization) of $70 \mathrm{eV}$, an interface temperature of $250^{\circ} \mathrm{C}$ and an ion source temperature of

$205200^{\circ} \mathrm{C}$ was used. The detection of the mass fragments was finally carried out in the scan

206 mode from 40 to $600 \mathrm{~m} / \mathrm{z}$.

\section{Product purification and identification}

209 For product purification, the supernatant of the duplicates $(2 \times 50 \mathrm{~mL}$ or $2 \times 400 \mathrm{~mL})$ from

210 preparative biotransformations were extracted twice with the identical volume of MTBE.

211 In the case of biotransformations with substrate $\mathbf{6}, \mathbf{8}$ and $\mathbf{1 2}$, the supernatant was

212 additionally acidified with $\mathrm{HCl}$ and afterwards extracted with MTBE. The organic phases

213 were combined, evaporated to dryness and the residues were dissolved in $10 \mathrm{~mL}$ of

214 acetonitrile and stored at $4^{\circ} \mathrm{C}$ for further use. The batches were finally purified by reverse

215 phase semi-preparative HPLC on an Agilent 1200 System (St. Clara, California, USA)

216 equipped with a G1311A quaternary pump, a HIP AS G1367B autosampler (1200 $\mu \mathrm{L}$

217 loop), a G1315D DAD detector and an analytical G1364C fraction collector. The

218 separation of the analytes (injection volume: $1000 \mu \mathrm{L}$ ) was ensured using a Trentec

219 Reprosil@ 100-5 C18 column $(250 \times 20$ mm, $5 \mu \mathrm{m})$ from Dr. Maisch GmbH (Ammerbuch-

220 Entringen, Germany). The mobile phases A and B were composed of water containing

$2210.1 \%$ formic acid and acetonitrile, respectively. Elution was done in a gradient mode at a

222 flow rate of $5 \mathrm{~mL} \mathrm{~min}^{-1}$ and a column temperature of $20^{\circ} \mathrm{C}$ using following program:

$22385 \% \mathrm{~A}(0 \mathrm{~min}), 20 \% \mathrm{~A}(63 \mathrm{~min}), 20 \% \mathrm{~A}(67 \mathrm{~min}), 85 \% \mathrm{~A}(67.01 \mathrm{~min}), 85 \% \mathrm{~A}(83 \mathrm{~min})$. 
224 The elution of substrates and products were followed spectrophotometrically at a

225 wavelength of $272 \mathrm{~nm}$ for $\mathbf{1}, 232 \mathrm{~nm}$ for $\mathbf{6}, 224 \mathrm{~nm}$ for $\mathbf{8}$ and $275 \mathrm{~nm}$ for $\mathbf{1 2}$. Identical

226 product fractions were combined, the solvent mixture of acetonitrile and water removed on

227 a rotary evaporator and completely dried by a nitrogen gas flow. The remaining solid

228 products were finally dissolved in $d$-methanol or $d$-DMSO and analyzed by ${ }^{1} \mathrm{H}$ - and ${ }^{13} \mathrm{C}$ -

229 NMR to clarify the chemical structures. The purity of all samples were determined by GC

230 or HPLC.

\section{$232 \quad$ NMR measurements}

233 For the characterization of the purified products, NMR spectroscopy was used. ${ }^{1} \mathrm{H}-$,

$234{ }^{1} \mathrm{H}-\mathrm{COSY}$ - and ${ }^{13} \mathrm{C}-\mathrm{NMR}$ spectra were recorded using a Bruker Avance 500 spectrometer

235 at 500.15 and $125.76 \mathrm{MHz}$, respectively, or a Bruker Ascend $700{ }^{\mathrm{TM}}$ spectrometer at 700.36

236 and 176.10 MHz respectively (both Bruker, Billerica, Massachusetts, USA). The chemical

237 shift $\delta$ was measured in ppm (parts per million) and referred to TMS (tetramethylsilane)

$238 \delta=0 \mathrm{ppm}$ as a standard. Unless otherwise stated, $10 \mathrm{mg}$ of the product was used for NMR

239 analysis. The NMR spectra are given in the supplemental material (Figures S2-S9).

240 5-Hydroxydiclofenac: ${ }^{1} \mathrm{H}-\mathrm{NMR}\left(500 \mathrm{MHz}, \mathrm{CD}_{3} \mathrm{OD}\right): \delta$ (ppm) 3.71 (s, 2H; C-7), 6.37 (d, $J$

$241=8.8 \mathrm{~Hz}, 1 \mathrm{H} ; \mathrm{C}-3), 6.55(\mathrm{dd}, J=8.8,2.5 \mathrm{~Hz}, 1 \mathrm{H} ; \mathrm{C}-4), 6.72(\mathrm{~d}, J=2.5 \mathrm{~Hz}, 1 \mathrm{H} ; \mathrm{C}-6), 6.96$

$242(\mathrm{t}, J=7.8 \mathrm{~Hz}, 1 \mathrm{H}$; C-4'), 7.34 (d, $J=7.8 \mathrm{~Hz} 2 \mathrm{H}$; C-3' and 5').

$243{ }^{13} \mathrm{C}-\mathrm{NMR}\left(126 \mathrm{MHz}, \mathrm{CD}_{3} \mathrm{OD}\right): \delta(\mathrm{ppm}) 39.2(\mathrm{C} 7), 115.3$ (ArCH-4), 118.3 (ArCH-6), 121.9

244 (ArCH-3), 124.1 (ArCH-4'), 129.2 (ArC-2), 129.3 (ArC-1'), 130.1 (2ArCH-3' and 5'),

$245136.4($ ArC-1), $140.5(2 \mathrm{CCl}), 154.1(\mathrm{C}-\mathrm{OH}), 175.8(\mathrm{COOH})$. 
246 5-Hydroxyquinoneimine: ${ }^{1} \mathrm{H}-\mathrm{NMR}\left(500 \mathrm{MHz},\left(\mathrm{CD}_{3}\right)_{2} \mathrm{SO}\right): \delta(\mathrm{ppm}) 3.69$ (s, 2H; C-7), 6.59

247 (dd, $J=10.1,2.5 \mathrm{~Hz}, 1 \mathrm{H} ; \mathrm{C}-4), 6.74(\mathrm{~d}, J=10.1 \mathrm{~Hz}, 1 \mathrm{H} ; \mathrm{C}-3), 6.80$ (d, $J=2.5 \mathrm{~Hz}, 1 \mathrm{H}$; C-

248 6), $7.25\left(\mathrm{t}, J=8.2 \mathrm{~Hz}, 1 \mathrm{H} ; \mathrm{C}^{-4}{ }^{\prime}\right), 7.58\left(\mathrm{~d}, J=7.6 \mathrm{~Hz}, 2 \mathrm{H} ; \mathrm{C}-3^{\prime}\right.$ and 5').

$249{ }^{13} \mathrm{C}-\mathrm{NMR}\left(126 \mathrm{MHz},\left(\mathrm{CD}_{3}\right)_{2} \mathrm{SO}\right): \delta$ (ppm) 36.3 (C7), 123.1 (ArC), 126.6 (ArC), 128.6

250 (ArC), 129.1 (ArC), 133.1 (ArC), 133.5 (ArC), 143.4 (ArC-1'), 145.1 (ArC-1), 160.4 (ArC-

$2512), 170.6(\mathrm{COOH}), 186.9(\mathrm{C}=\mathrm{O})$.

252 4'-Hydroxydiclofenac: ${ }^{1} \mathrm{H}-\mathrm{NMR}\left(500 \mathrm{MHz}, \mathrm{CD}_{3} \mathrm{OD}\right): \delta(\mathrm{ppm}) 3.7$ (s, 2H, C-7), 6.26 (d, 1H, $253 J=8.0 \mathrm{~Hz}, \mathrm{C}-3), 6.8(\mathrm{t}, 1 \mathrm{H}, J=7.4, \mathrm{C}-5), 6.88\left(\mathrm{~s}, 2 \mathrm{H}, \mathrm{C}-3^{`}\right.$ and C-5 $), 7.02(\mathrm{t}, 1 \mathrm{H}, J=7.5$, $254 \mathrm{C}-4), 7.17(\mathrm{~d}, 1 \mathrm{H}, J=7.4, \mathrm{C}-6)$.

$255{ }^{1} \mathrm{H}-\mathrm{COSY}\left(500 \mathrm{MHz}, \mathrm{CD}_{3} \mathrm{OD}\right):(7.17) \delta(\mathrm{ppm}) 3.7,6.8,(7.02) \delta(\mathrm{ppm}) 6.26,6.8$.

$256{ }^{13} \mathrm{C}-\mathrm{NMR}\left(126 \mathrm{MHz}, \mathrm{CD}_{3} \mathrm{OD}\right): \delta$ (ppm) 39.2 (C7`), 116.4 (ArC), 116.9 (2ArC), 121.3 257 (ArC), 124.2 (ArC), 128.9 (ArC), 130.5 (ArC), 131.9 (2ArC), 133.7 (ArC), 145.5 (ArC), $258156.3\left(\mathrm{ArC}^{-4}\right), 175.9(\mathrm{COOH})$.

259 3',4'-Dihydroxydiclofenac: ${ }^{1} \mathrm{H}$ NMR (700 MHz, CD ${ }_{3} \mathrm{OD}$ ): $\delta(\mathrm{ppm}) 3.72$ (s, 2H, C-7), 6.29

$260(\mathrm{~d}, 1 \mathrm{H}, J=8.1 \mathrm{~Hz}, \mathrm{C}-3), 6.80(\mathrm{t}, 1 \mathrm{H}, J=7.6, \mathrm{C}-5), 6.86(\mathrm{~s}, 1 \mathrm{H}, \mathrm{C}-5)$ ) $7.02(\mathrm{t}, 1 \mathrm{H}, J=7.9$ $261 \mathrm{~Hz}, \mathrm{C}-4), 7.17$ (d, 1H, 3.5 Hz, C-6).

262 6-o-Desmethylnaproxen: ${ }^{1} \mathrm{H}-\mathrm{NMR}\left(500 \mathrm{MHz}, \mathrm{CD}_{3} \mathrm{OD}\right): \delta(\mathrm{ppm}) 1.50(\mathrm{~d}, 3 \mathrm{H}, J=7.0 \mathrm{~Hz}$, $263 \mathrm{C}-3), 3.81(\mathrm{q}, 1 \mathrm{H}, J=7.2 \mathrm{~Hz}, \mathrm{C}-2), 7.03-7.09(\mathrm{~m}, 2 \mathrm{H}, \mathrm{C}-8$ and C-10) 7.35 (d, 1H, $J=8.5$ $264 \mathrm{~Hz}, \mathrm{C}-11), 7.59$ (d, 1H, $J=8.4 \mathrm{~Hz}, \mathrm{C}-13), 7.64$ (s, 1H, C-5), 7.67 (d, 1H, J=8.8 Hz, C-6). $265{ }^{13} \mathrm{C}-\mathrm{NMR}\left(126 \mathrm{MHz}, \mathrm{CD}_{3} \mathrm{OD}\right): \delta(\mathrm{ppm}) 15.4$ (C7), $113.2(\mathrm{ArC}), 114.5$ (ArC), $117.9(\mathrm{ArC})$, 266127.3 (ArC), 127.5 (ArC), 128.7 (ArC), 133.3 (ArC), 134.9 (ArC), 135.1 (ArC), 135.2 267 (ArC), $141.6(\mathrm{ArC}), 150.2(\mathrm{ArC}), 172.1(\mathrm{COOH})$. 
2-Hydroxyibuprofen: ${ }^{1} \mathrm{H}-\mathrm{NMR}\left(500 \mathrm{MHz}, \mathrm{CD}_{3} \mathrm{OD}\right): \delta$ (ppm) 1.16 (s, 6H, C-12 and C-13), $2691.43(\mathrm{~d}, 3 \mathrm{H}, J=7.2 \mathrm{~Hz}, \mathrm{C}-3), 2.72(\mathrm{~s}, 2 \mathrm{H}, \mathrm{C}-10), 3.68$ (q, 1H, J = 7.2 Hz, C-2), 7.18 (d, $2702 \mathrm{H}, J=8.0 \mathrm{~Hz}, \mathrm{C}-5$ and C-9), $7.22(\mathrm{~d}, 2 \mathrm{H}, J=7.9 \mathrm{~Hz}, \mathrm{C}-6$ and C-8).

$271{ }^{13} \mathrm{C}-\mathrm{NMR}\left(126 \mathrm{MHz}, \mathrm{CD}_{3} \mathrm{OD}\right): \delta(\mathrm{ppm}) 19.1$ (C3), 29.2 (C12 and C13), $46.4(\mathrm{C} 2), 50.3$

272 (C10), 71.8 (C11), 128.0 (2x ArC), 131.9 (2 x ArC), 138.5 and 140.3 (C4 and C7), 178.6 $273(\mathrm{COOH})$.

274 1-Hydroxyibuprofen: ${ }^{1} \mathrm{H}-\mathrm{NMR}\left(700 \mathrm{MHz},\left(\mathrm{CD}_{3}\right)_{2} \mathrm{SO}\right): \delta(\mathrm{ppm}) 0.73(\mathrm{~d}, 3 \mathrm{H}, J=6.8 \mathrm{~Hz}, \mathrm{C}-$ 275 12) $0.85(\mathrm{~d}, 3 \mathrm{H}, J=6.7 \mathrm{~Hz}, \mathrm{C}-13), 1.32$ (d, 3H, $J=7.1 \mathrm{~Hz}, \mathrm{C}-3), 1.77$ (oct, $1 \mathrm{H}, J=16.4$ $276 \mathrm{~Hz}, \mathrm{C}-11), 3.58$ (q, 1H, J = 7.2 Hz, C-2), 4.19 (d, 1H, J=6.2, C-10), 7.19 (d, 2H, $J=8.5$ $277 \mathrm{~Hz}, \mathrm{C}-5$ and C-9), 7.21 (d, 2H, $J=8.6 \mathrm{~Hz}, \mathrm{C}-6$ and C-8).

$278{ }^{13} \mathrm{C}-\mathrm{NMR}\left(176 \mathrm{MHz},\left(\mathrm{CD}_{3}\right)_{2} \mathrm{SO}\right): \delta(\mathrm{ppm}) 17.4(\mathrm{C} 3), 18.2$ and 18.5 (C12 and C13), 34.3 279 (C11), $44.4(\mathrm{C} 2), 76.8(\mathrm{C} 10), 125.9$ and 126.1 (4 x ArC), 139.6 and 142.6 (C4 and C7), $280175.3(\mathrm{COOH})$.

281 1,2-Dihydroxyibuprofen: ${ }^{1} \mathrm{H}-\mathrm{NMR}\left(500 \mathrm{MHz}, \mathrm{CD}_{3} \mathrm{OD}\right): \delta(\mathrm{ppm}) 1.12$ (s, 6H, C-12 and C$28213), 1.43$ (d, 3H, $J=3.4 \mathrm{~Hz}, \mathrm{C}-3), 3.69$ (q, 1H, $J=7.2 \mathrm{~Hz}, \mathrm{C}-2), 4.43$ (s, 1H, C-10), 7.26 $283(\mathrm{~d}, 2 \mathrm{H}, J=7.8 \mathrm{~Hz}, \mathrm{C}-5$ and C-9), $7.34(\mathrm{~d}, 2 \mathrm{H}, J=8.0 \mathrm{~Hz}, \mathrm{C}-6$ and C-8).

$284{ }^{13} \mathrm{C}-\mathrm{NMR}\left(126 \mathrm{MHz}, \mathrm{CD}_{3} \mathrm{OD}\right): \delta$ (ppm) 19.1 (C3), 25.3 and 26.0 (C12 and C13), 46.7 285 (C2), 74.0 (C11), 81.6 (C10), 127.8 (2 x ArC), 129.2 (2 x ArC), 141.7 and 141.8 (C4 and 286 C7). $\mathrm{COOH}$ group is barely visible.

287 3'-Hydroxymethylmefenamic acid: ${ }^{1} \mathrm{H}-\mathrm{NMR}\left(500 \mathrm{MHz},\left(\mathrm{CD}_{3}\right)_{2} \mathrm{SO}\right): \delta(\mathrm{ppm}) 2.11(\mathrm{~s}, 3 \mathrm{H}$, 288 C-8'), 4.53 (s, 2H, C-7'), $6.68-6.73$ (m, 2H, C-2 and C-4), $7.18-7.25$ (m, 3H, C-4', 5' 289 and 6'), $7.31(\mathrm{t}, 1 \mathrm{H}, J=7.5 \mathrm{~Hz}, \mathrm{C}-3), 7.89(\mathrm{~d}, 1 \mathrm{H}, J=7.5 \mathrm{~Hz}, \mathrm{C}-5)$. 
${ }^{13} \mathrm{C}-\mathrm{NMR}\left(126 \mathrm{MHz},\left(\mathrm{CD}_{3}\right)_{2} \mathrm{SO}\right): \delta(\mathrm{ppm}) 12.4\left(\mathrm{C}^{\circ}\right), 61.3\left(\mathrm{C}^{\circ}\right), 111.6$ (ArC), 112.9

291 (ArC), 116.3 (2ArC-3 and 4`), 122.6 (ArC), 123.5 (ArC), 125.9 (ArC), 129.9 (ArC), 131.6

292 (ArC), 134.0 (ArC), 138.2 (ArC), 141.8 (ArC), $170.0(\mathrm{COOH})$.

293 3'-Carboxymefenamic acid: ${ }^{1} \mathrm{H}-\mathrm{NMR}\left(500 \mathrm{MHz},\left(\mathrm{CD}_{3} \mathrm{OD}\right): \delta(\mathrm{ppm}) 2.43\right.$ (s, 3H, C-8'),

$2946.71(\mathrm{t}, 1 \mathrm{H}, J=7.5 \mathrm{~Hz}, \mathrm{C}-4), 6.75(\mathrm{~d}, 1 \mathrm{H}, J=4.3 \mathrm{~Hz}, \mathrm{C}-2), 7.28(\mathrm{q}, 2 \mathrm{H}, J=7.3 \mathrm{~Hz}, \mathrm{C}-3$,

295 and C-5'), $7.46\left(\mathrm{~d}, 1 \mathrm{H}, J=7.8 \mathrm{~Hz}, \mathrm{C}-4^{\prime}\right), 7.62\left(\mathrm{~d}, 1 \mathrm{H}, J=7.8 \mathrm{~Hz}, \mathrm{C}-6^{\prime}\right), 7.98(\mathrm{~d}, 1 \mathrm{H}, J=$ $2968.0 \mathrm{~Hz}, \mathrm{C}-5)$.

$297{ }^{13} \mathrm{C}-\mathrm{NMR}\left(126 \mathrm{MHz},\left(\mathrm{CD}_{3} \mathrm{OD}\right): \delta(\mathrm{ppm}) 15.4\left(\mathrm{C} 8^{\circ}\right), 113.2\right.$ (ArC), 114.5 (ArC), 117.9 298 (ArC), 127.3 (ArC), 127.5 (ArC), 128.7 (ArC), 133.3 (ArC), 134.9 (ArC), 135.1 (ArC), $299135.2(\mathrm{ArC}), 141.6(\mathrm{ArC}), 150.2(\mathrm{ArC}), 172.1(2 \times \mathrm{COOH})$.

$301 \quad$ Results and Discussion

302 Identification of microbial biocatalysts for NSAID oxyfunctionalizations

303 In addition to the already published organism Beauveria bassiana, which is able to perform

304 one of the most effective hydroxylation processes in biocatalysis, the production of $(R)-2$ -

305 (4-hydroxyphenoxy)propionic acid and a variety of other hydroxylation reactions $(31,32)$,

306 we identified two other filamentous fungi as further novel NSAID accepting biocatalysts.

307 One of these strains was isolated from soil samples close to Ludwigshafen (Germany)

308 during previous diclofenac (1) degradation experiments (33). The third filamentous fungus

309 was isolated by coincident as a contamination strain out of a 5-hydroxydiclofenac (3)

310 standard, diluted in M9 minimal medium, after 1.5 years of aerobic incubation. Both fungi

311 were assigned by the universal biomarkers LSU (28S nuclear ribosomal large subunit

312 rRNA gene) and ITS (internal transcribed spacer). Sequence matching with the fungal 
313 barcoding and the NCBI database revealed that one strain was > 99\% consistent with the

314 S1 organism Clitocybe nebularis (confirmed by LSU and ITS biomarkers). For the other

315 organism, the LSU biomarker found a >98\% similarity with the S1 organism

316 Mucor hiemalis.

317 Biotransformations with diclofenac

318 The fungi were cultivated in $400 \mathrm{~mL}$ PGE broth and the biotransformations were done in

319 duplicates with a starting concentration of $0.6 \mathrm{~g} \mathrm{~L}^{-1}$ diclofenac (1). The reaction was

320 monitored over time by HPLC-DAD and stopped after $144 \mathrm{~h}$ (Figure 1). All products were

321 purified by semi-preparative HPLC for further detailed structure identification by ${ }^{1} \mathrm{H}$ and

$322{ }^{13} \mathrm{C}$ NMR. Similar to the distribution of products in humans, the 4'-position (2) was

323 favoured in the biotransformations with the fungi, which was also observed with P450s

324 and microorganisms in previous studies (Scheme 1, Table 1). In comparison to

325 C. nebularis which is able to catalyze a mixture of the metabolites 4'-hydroxydiclofenac

$326(2,60 \%), 5$-hydroxydiclofenac $(3,30 \%)$ and the corresponding quinoneimine $(4,10 \%)$

327 with $50.6 \%$ isolated yield, M. hiemalis selectively oxyfunctionalized diclofenac (1)

328 yielding $61.7 \%$ of 4'-hydroxydiclofenac (2) after purification. High isolated yields of

$32955.3 \%$ were additionally achieved using B. bassiana. Next to the major product

330 4'-hydroxydiclofenac (2, 90\%), a 3',4'-dihydroxydiclofenac (5) metabolite was identified

331 that has not been characterized and published yet. In studies concerning the fungi

332 Epicoccum nigrum and Cunninghamella elegans, preparative biotransformations were

333 performed resulting in product titers of 16 and $57 \mathrm{mg} \mathrm{L}^{-1}$, respectively $(34,35)$. In contrast,

334 the filamentous fungi identified in the present work were able to obtain significantly higher

335 values comparable with biotransformations using P450 RhF and P450 BM3 (Table 1). 
337 A common question that is often raised as a negative element for the use of microbial cell

338 factories is which enzymes are involved in the detected biotransformation. In this respect,

339 we aimed to identify 450s, which are responsible for the oxyfunctionalization of diclofenac

340 (1) and (R)-2-phenoxypropionic acid in B. bassiana using omics studies. As a proof of

341 concept, we analyzed biotransformation samples whether we can identify differences by a

342 proteome analysis depending on the substrate. Therefore, samples of biotransformations

343 with the corresponding substrates and glucose as negative control were processed to obtain

344 the organisms proteome. By applying the proteome analysis clear evidence of P450s

345 (implied by the number of detected and assigned fragments) which were upregulated with

346 the specific substrates, were achieved drastically reducing the high number of 83 putative

347 P450s in B. bassiana (36). With diclofenac (1) as substrate two P450s, CYP548A5 and

348 CYP51F1, were exclusively expressed compared to the samples exposed with the other

349 substrates (Table 2). In case of $(R)$-2-phenoxypropionic acid as substrate, CYP52A10

350 seems to be strongly upregulated while CYP684A2 was induced exclusively. In

351 eukaryotes, only one bifunctional NADPH-reductase serves as electron delivering partner

352 that was also found in all samples. In this work, the proteome analysis has thus proved to

353 be a targeted method for identifying involved proteins in eukaryotes that can subsequently

354 lead to valuable new heterologous expressed biocatalysts.

355 NSAID biotransformations applying the identified microbial biocatalysts

356 To investigate the potential of the microbial biocatalysts further we increased the NSAID

357 substrate scope of the fungi strains to oxyfunctionalize naproxen (6), ibuprofen (8) and

358 mefenamic acid (12). In some cases, high titers and full conversion towards the investigated 
359 NSAIDs were achieved. For example, $M$. hiemalis demethylated naproxen (6) to the human

360 metabolite 6-o-desmethylnaproxen (7) with an isolated yield of over $99 \%$ using $1 \mathrm{~g} \mathrm{~L}^{-1}$ of

361 substrate (Scheme 2). In comparison the in vitro biotransformations with P450 BM3

362 variants and the strain A. niger showed much lower selectivity and isolated yield (Table 1)

$363(19,20,37)$.

364 Furthermore, M. hiemalis almost completely hydroxylated $1 \mathrm{~g} \mathrm{~L}^{-1}$ ibuprofen (8) to the

365 metabolites 2-hydroxyibuprofen $(\mathbf{9}, 90 \%)$ 1-hydroxyibuprofen $(\mathbf{1 0}, 2 \%)$, and the double

366 hydroxylated secondary product 1,2-dihydroxyibuprofen $(\mathbf{1 1}, \mathbf{8 \%})$ (Scheme 2). The highest

367 product titer so far was achieved by a P450 BM3 variant in vitro with $0.4 \mathrm{~g} \mathrm{~L}^{-1}$ of

368 2-hydroxyibuprofen (9) (Table 1) (17, 20, 38). Microorganisms such as

369 Trametes versicolor and Nigospora sphaerica or the P450s CYP2C9, CYP267A1 and B1

370 had significantly lower product yields $\left(>30 \mathrm{~g} \mathrm{~L}^{-1}\right)(25,39-41)$. Using the anthranilic acid

371 derivative mefenamic acid (12) as substrate, the highest activity was achieved by

372 B. bassiana with an isolated yield of $48 \%$ at $1 \mathrm{~g} \mathrm{~L}^{-1}$ substrate concentration (Scheme 2).

373 Next to the 3'-hydroxymethylmefenamic acid (13) as main product (68\%), the product

374 3'-carboxymefenamic acid (14) was catalyzed. In humans, 12 is mainly converted to $\mathbf{1 3}$ by

375 CYP2C9 which undergoes further oxidation to the carboxy metabolite 14 (42). An evolved

376 P450 BM3 variant generated besides 3'-hydroxymethylmefenamic acid (13) the other

377 human P450 catalyzed metabolites 4'- and 5-hydroxymefenamic acid (20 and 21) which

378 are hydroxylated at the aromatic rings $(18,43)$. In this case, in vitro product titers of

$379216 \mathrm{mg} \mathrm{L}^{-1}$ were below those obtained with B. bassiana (Table 1). In degradation

380 experiments, the wild-type organism Phaenerochaete sordida (white-rot fungus) also 
381 produced different mefenamic acid metabolites with significantly lower yields of less than $3823 \mathrm{mg} \mathrm{L}^{-1}(26)$.

383 Overall, the filamentous fungi of the present study achieved high product titers in the

384 biotransformations with the NSAIDs. Applying a semi-preparative HPLC purification

385 method, all NSAID metabolites could be isolated in high yields and high purities.

386 Moreover, reproducible product titers were obtained at $50 \mathrm{~mL}$ or $400 \mathrm{~mL}$ scale exhibiting

387 the possibility to further increase the yields by improving the cultivation and

388 biotransformation procedure. One drawback of filamentous fungi as catalyst for

389 biotransformations is their mycelial growth. This particular cell shape minimizes the

390 possible surface to the medium and thus the mass transfer of substrate solubilized in the

391 medium and the cells. Especially cells located inside the mycelia may therefore be unable

392 to participate in biocatalysis, but against our expectation, the clump-forming organism

393 M. hiemalis has achieved the highest yields so far.

394 Compared to already published biotechnological processes the total process time with the

395 filamentous fungi of 4 days or 7 days for diclofenac (1), respectively, were in accordance

396 with most of the studies (Table 1 and 2). However, a simple cultivation and

397 biotransformation setup using fungi with less steps are main benefits, besides the achieved

398 high product yields. In detail, compared to P450-based reactions, less requirements on the

399 process were necessary since issues associated with an often complex P450 system like

400 biocatalyst expression, stability or cofactor dependency are negligible.

401

402 In conclusion, the results of the present work demonstrate the potential of microbial 403 biocatalysts for NSAID oxyfunctionalizations. Often, low activity, difficult handling, or 
404 high by-product formation are illustrated as criteria against the use of microorganisms (40).

405 In contrast, the microorganisms identified in this work are easy to cultivate, inexpensive

406 and are able to produce high valued metabolites in promising yields. The applied and

407 identified filamentous fungi serve with their versatile metabolism as an interesting platform

408 for novel cell factories to produce valuable NSAID metabolites in an effective and cheap

409 way or can help to develop new strategies in drug design.

\section{Acknowledgements}

412 The research leading to these results has received funding from the European Union's

413 Seventh Framework Programme for research, technological development and

414 demonstration under grant agreements no 613849 (BIOOX). We also gratefully

415 acknowledge financial support from the Landesgraduiertenförderung (LSFG) Baden-

416 Württemberg. We thank Berit Würtz and Dr. Jens Pfannstiel for conduction and helpful

417 advice concerning the proteome analysis.

\section{References}

420 1. Bernhardt R. 2004. Cytochrome P450 : versatile Enzymsysteme mit Anwendungen 421 in der Biotechnologie und Medizin. Mag Forsch 1:10-16.

422 2. Guengerich FP. 2008. Cytochrome P450 and Chemical Toxicology Cytochrome 423 P450 and Chemical Toxicology. Chem Res Toxicol 21:70-83.

424 3. Guengerich F. 2006. Cytochrome P450s and other enzymes in drug metabolism and $425 \quad$ toxicity. AAPS J 8:E101-E111.

426 4. Naisbitt DJ, Sanderson LS, Meng X, Stachulski A V., Clarke SE, Park BK. 2007. 
427 Investigation of the immunogenicity of diclofenac and diclofenac metabolites.

$428 \quad$ Toxicol Lett 168:45-50.

429 5. den Braver MW, Zhang Y, Venkataraman H, Vermeulen NPE, Commandeur JNM.

430 2016. Simulation of interindividual differences in inactivation of reactive para-

431 benzoquinone imine metabolites of diclofenac by glutathione S-transferases in

432 human liver cytosol. Toxicol Lett 255:52-62.

433 6. Langford K, Thomas K V. 2011. Input of selected human

434 pharmaceuticalmetabolites into the Norwegian aquatic environment. J Environ

$435 \quad$ Monit 13:416-421.

436 7. Richardson SD, Kimura SY. 2016. Water Analysis: Emerging Contaminants and

437 Current Issues. Anal Chem 88:546-582.

438 8. Guengerich FP, MacDonald JS. 2007. Applying mechanisms of chemical toxicity to 439 predict drug safety. Chem Res Toxicol 20:344-369.

440 9. Daily EB, Aquilante CL. 2009. Cytochrome P450 2C8 pharmacogenetics: a review 441 of clinical studies. Pharmacogenomics 10:1489-1510.

442 10. Waterhouse I. 1999. Synthesis of deuterium labelled 4'-Hydroxydiclofenac. J Label 443 Compd Radiopharm 42:1075-1083.

444 11. Kim SH, Kwon JH, Yoon SH. 2010. An improved synthesis of 4'445 hydroxydiclofenac. Bull Korean Chem Soc 31:3007-3009.

446 12. Kenny JR, Maggs JL, Meng X, Sinnott D, Clarke SE, Park BK, Stachulski A V. 447 2004. Syntheses and characterization of the acyl glucuronide and hydroxy 448 metabolites of diclofenac. J Med Chem 47:2816-2825.

449 13. Urlacher VB, Girhard M. 2012. Cytochrome P450 monooxygenases: an update on 
perspectives for synthetic application. Trends Biotechnol 30:26-36.

451 14. Drăgan CA, Peters FT, Bour P, Schwaninger AE, Schaan SM, Neunzig I, Widjaja M, Zapp J, Kraemer T, Maurer HH, Bureik M. 2011. Convenient gram-scale metabolite synthesis by engineered fission yeast strains expressing functional human P450 systems. Appl Biochem Biotechnol 163:965-980.

455 15. Geier M, Braun A, Emmerstorfer A, Pichler H, Glieder A. 2012. Production of human cytochrome P450 2D6 drug metabolites with recombinant microbes - a comparative study. Biotechnol J 7:1346-1358.

458 16. Vail RB, Homann MJ, Hanna I, Zaks A. 2005. Preparative synthesis of drug metabolites using human cytochrome P450s 3A4, 2C9 and 1A2 with NADPH-P450 reductase expressed in Escherichia coli. J Ind Microbiol Biotechnol 32:67-74.

461 17. Tsotsou GE, Sideri A, Goyal A, Di Nardo G, Gilardi G. 2012. Identification of mutant Asp251Gly/Gln307His of cytochrome P450 BM3 for the generation of metabolites of diclofenac, ibuprofen and tolbutamide. Chem - A Eur J 18:35823588.

465 18. Venkataraman H, Verkade-Vreeker MCA, Capoferri L, Geerke DP, Vermeulen NPE, Commandeur JNM. 2014. Application of engineered cytochrome P450 mutants as biocatalysts for the synthesis of benzylic and aromatic metabolites of fenamic acid NSAIDs. Bioorganic Med Chem 22:5613-5620. 

3:1065-1071.

475 21. Klenk JM, Nebel BA, Porter JL, Kulig JK, Hussain SA, Richter SM, Tavanti M, 476 Turner NJ, Hayes MA, Hauer B, Flitsch SL. 2017. The self-sufficient P450 RhF 477 expressed in a whole cell system selectively catalyses the 5-hydroxylation of 478 diclofenac. Biotechnol J 12:1-8.

479 22. Xu LH, Ikeda H, Liu L, Arakawa T, Wakagi T, Shoun H, Fushinobu S. 2015. 480 Structural basis for the 4'-hydroxylation of diclofenac by a microbial cytochrome $481 \quad$ P450 monooxygenase. Appl Microbiol Biotechnol 99:3081-3091.

482 23. Marco-Urrea E, Pérez-Trujillo M, Cruz-Morató C, Caminal G, Vicent T. 2010. 483 Degradation of the drug sodium diclofenac by Trametes versicolor pellets and identification of some intermediates by NMR. J Hazard Mater 176:836-842.

485 24. Ferrando-Climent L, Collado N, Buttiglieri G, Gros M, Rodriguez-Roda I, 486 Rodriguez-Mozaz S, Barceló D. 2012. Comprehensive study of ibuprofen and its 487 metabolites in activated sludge batch experiments and aquatic environment. Sci $488 \quad$ Total Environ 438:404-413.

489 25. Borges KB, De Oliveira ARM, Barth T, Jabor VAP, Pupo MT, Bonato PS. 2011. 490 LC-MS-MS determination of ibuprofen, 2-hydroxyibuprofen enantiomers, and 491 carboxyibuprofen stereoisomers for application in biotransformation studies 492 employing endophytic fungi. Anal Bioanal Chem 399:915-925.

493 26. Hata T, Kawai S, Okamura H, Nishida T. 2010. Removal of diclofenac and 494 mefenamic acid by the white rot fungus Phanerochaete sordida YK-624 and 495 identification of their metabolites after fungal transformation. Biodegradation 
497 27. Schoch CL, Seifert K a., Huhndorf S, Robert V, Spouge JL, Levesque C a., Chen W, Consortium FB, Bolchacova E, Voigt K, Crous PW, Miller a. N, Wingfield MJ,

De Beer ZW, de Hoog GS, Del-Prado R, Dentinger B, Dieguez-Uribeondo J, 

BS, Weiss M, White MM, Xu J, Yahr R, Yang ZL, Yurkov A, Zamora J-C, Zhang spacer (ITS) region as a universal DNA barcode marker for Fungi. Proc Natl Acad Sci U S A 109:1-6.

524 28. Osherov N, May GS. 1998. Optimization of protein extraction from Aspergillus 525 nidulans for gel electrophoresis. Fungal Genet Newsl 45:38-40.

526 29. Voolstra O, Beck K, Oberegelsbacher C, Pfannstiel J, Huber A. 2010. Light527 dependent phosphorylation of the Drosophila transient receptor potential ion 528 channel. J Biol Chem 285:14275-14284.

529 30. Vizcaíno JA, Csordas A, Del-Toro N, Dianes JA, Griss J, Lavidas I, Mayer G, Perez530 Riverol Y, Reisinger F, Ternent T, Xu QW, Wang R, Hermjakob H. 2016. 2016 $531 \quad$ update of the PRIDE database and its related tools. Nucleic Acids Res 44:D447$532 \quad$ D456.

533 31. Dingler C, Ladner W, Krei GA, Cooper B, Hauer B. 1996. Preparation of (R)-2-(4534 Hydroxyphenoxy) propionic Acid by Biotransformation. Pestic Sci 46:33-35.

535 32. Grogan GJ, Holland HL. 2000. The biocatalytic reactions of Beauveria spp . J Mol $536 \quad$ Catal B Enzym 9:1-32.

537 33. Facey SJ, Nebel BA, Kontny L, Allgaier M, Hauer B. 2018. Rapid and complete 538 degradation of diclofenac by native soil microorganisms. Environ Technol Innov $539 \quad 10: 55-61$.

540 34. Webster R, Pacey M, Winchester T, Johnson P, Jezequel S. 1998. Microbial 541 oxidative metabolism of diclofenac: Production of 4'-hydroxydiclofenac using 
542 Epicoccum nigrum IMI354292. Appl Microbiol Biotechnol 49:371-376.

543 35. Quinn L, Dempsey R, Casey E, Kane A, Murphy CD. 2015. Production of drug

544 metabolites by immobilised Cunninghamella elegans: from screening to scale up. J

$545 \quad$ Ind Microbiol Biotechnol 42:799-806.

546 36. Xiao G, Ying S-H, Zheng P, Wang Z-L, Zhang S, Xie X-Q, Shang Y, St Leger RJ,

547 Zhao G-P, Wang C, Feng M-G. 2012. Genomic perspectives on the evolution of

548 fungal entomopathogenicity in Beauveria bassiana. Sci Rep 2:483.

549 37. He A, Rosazza JPN. 2003. Microbial transformations of S-naproxen by Aspergillus

$550 \quad$ niger ATCC 9142. Pharmazie 58:420-422.

551 38. Di Nardo G, Dell'Angelo V, Catucci G, Sadeghi SJ, Gilardi G. 2015. Subtle

552 structural changes in the Asp251Gly/Gln307His P450 BM3 mutant responsible for

553 new activity toward diclofenac, tolbutamide and ibuprofen. Arch Biochem Biophys

$554 \quad 602: 106-115$.

555 39. Marco-Urrea E, Pérez-Trujillo M, Vicent T, Caminal G. 2009. Ability of white-rot

556 fungi to remove selected pharmaceuticals and identification of degradation products

557 of ibuprofen by Trametes versicolor. Chemosphere 74:765-772.

558 40. Kern F, Khatri Y, Litzenburger M, Bernhardt R. 2016. CYP267A1 and CYP267B1

559 from sorangium cellulosum so ce56 are highly versatile drug metabolizers. Drug

$560 \quad$ Metab Dispos 44:495-504.

561 41. Neunzig I, Göhring A, Drăgan CA, Zapp J, Peters FT, Maurer HH, Bureik M. 2012.

562 Production and NMR analysis of the human ibuprofen metabolite 3-

563 hydroxyibuprofen. J Biotechnol 157:417-420.

564 42. Venkataraman H, Den Braver MW, Vermeulen NPE, Commandeur JNM. 2014. 
Cytochrome P450-mediated bioactivation of mefenamic acid to quinoneimine

566 intermediates and inactivation by human glutathione S-transferases. Chem Res

$567 \quad$ Toxicol 27:2071-2081.

568 43. Capoferri L, Leth R, ter Haar E, Mohanty AK, Grootenhuis PDJ, Vottero E,

569 Commandeur JNM, Vermeulen NPE, Jørgensen FS, Olsen L, Geerke DP. 2016.

570 Insights into regioselective metabolism of mefenamic acid by cytochrome P450

571 BM3 mutants through crystallography, docking, molecular dynamics, and free

572 energy calculations. Proteins Struct Funct Bioinforma 84:383-396.

573 44. Osorio-Lozada A, Surapaneni S, Skiles GL, Subramanian R. 2008. Biosynthesis of

574 drug metabolites using microbes in hollow fiber cartridge reactors: Case study of

575 diclofenac metabolism by actinoplanes species. Drug Metab Dispos 36:234-240.

576 45. Tavanti M, Porter JL, Sabatini S, Turner NJ, Flitsch SL. 2018. Panel of New

577 Thermostable CYP116B Self-Sufficient Cytochrome P450 Monooxygenases that

578 Catalyze C-H Activation with a Diverse Substrate Scope. ChemCatChem 10:1042-

5791051.

580

581 Table legends

582

583 ТAB 1

584 Summary of biotechnological processes to produce NSAID metabolites.

585 4'-hydroxydiclofenac (2); 5-hydroxydiclofenac (3); 5-hydroxyquinoneimine (4);

586 3',4'-dihydroxydiclofenac (5); 4',5-dihydroxydiclofenac (15); 6-o-desmethylnaproxen (7);

587 2-hydroxyibuprofen (9); 1-hydroxyibuprofen (10); 1,2-dihydroxyibuprofen (11); 
588 3'-hydroxymethylmefenamic acid (13); 3'-carboxymefenamic acid (14); 2-Acetyl-6-

589 methoxynaproxen (16); 7-hydroxynaproxen (17); 3',5-dihydroxymefenamic acid (18);

$590 \quad$ 3',6'-dihydroxymefenamic acid (19); 4'-hydroxymefenamic acid (20);

591 5-hydroxymefenamic acid (21).

592

593

594

595

596

597

598

599

600

601 


\begin{tabular}{|c|c|c|c|c|}
\hline Biocatalyst & Product(s) & Process time $^{\text {a) } / \text { Scale }}$ & Product titer & Reference \\
\hline \multicolumn{5}{|l|}{ Diclofenac (1) } \\
\hline E. nigrum & $2(>90 \%)$ & 2 d / 20 L (Reactor) & $\left.16 \mathrm{mg} \mathrm{L}^{-1} \mathrm{~b}\right)$ & (34) \\
\hline CYP267B1 (E. coli) & 2 & $3 \mathrm{~d} / 50 \mathrm{~mL}$ & $24 \mathrm{mg} \mathrm{L}^{-1}$ & $(40)$ \\
\hline CYP105D7 (E. coli) & 2 & $1.5 \mathrm{~d} / 0.5 \mathrm{~mL}$ & $44 \mathrm{mg} \mathrm{L}^{-1}$ & $(22)$ \\
\hline C. elegans & 2 & $18 \mathrm{~d} / 45 \mathrm{~mL}$ & $57 \mathrm{mg} \mathrm{L}^{-1 \mathrm{~b})}$ & (35) \\
\hline $\begin{array}{l}\text { B. bassiana } \\
\text { C. nebularis } \\
\text { M. hiemalis }\end{array}$ & $2,3,4,5$ & $7 \mathrm{~d} / 400 \mathrm{~mL}$ & $\left.320-390 \mathrm{mg} \mathrm{L}^{-1} \mathrm{~b}\right)$ & This study \\
\hline CYP2C9 (S. pombe) & 2 & $6 \mathrm{~d} / 1000 \mathrm{~mL}$ & $\left.468 \mathrm{mg} \mathrm{L}^{-1} \mathrm{~b}\right)$ & (14) \\
\hline P450 BM3 variants ${ }^{c)}$ & $\mathbf{2}(42 \%), \mathbf{3}(58 \%)$ & - & $512 \mathrm{mg} \mathrm{L}^{-1 \mathrm{~b})}$ & (19) \\
\hline $\mathrm{P} 450 \mathrm{RhF}($ E. coli $)$ & 3 & $2 \mathrm{~d} / 800 \mathrm{~mL}$ (Reactor) & $357 / \max .580 \mathrm{mg} \mathrm{L}^{-1}$ & $(21)$ \\
\hline Actinoplanes sp. & $\mathbf{2}(72 \%), \mathbf{3}(18 \%), \mathbf{1 5}(10 \%)$ & $5 \mathrm{~d} / 100 \mathrm{~mL}$ & $\left.848 \mathrm{mg} \mathrm{L}^{-1} \mathrm{~b}\right)$ & (44) \\
\hline CYP116B64 (E. coli) & 3 & $2 \mathrm{~d} / 100 \mathrm{~mL}$ & $1600 \mathrm{mg} \mathrm{L}^{-1}$ & $(45)$ \\
\hline \multicolumn{5}{|l|}{ Naproxen (6) } \\
\hline P450 BM3 variants ${ }^{c)}$ & $7(66 \%), 16(34 \%)$ & - & Max. $144 \mathrm{mg} \mathrm{L}^{-1 \mathrm{~b})}$ & $(19)(20)$ \\
\hline A. niger & $7(73 \%), 17(27 \%)$ & $2.5 \mathrm{~d} / 200 \mathrm{~mL}$ & $220 \mathrm{mg} \mathrm{L}^{-1 \mathrm{~b})}$ & $(37)$ \\
\hline M. hiemalis & 7 & $4 \mathrm{~d} / 50 \mathrm{~mL}$ & $980 \mathrm{mg} \mathrm{L}^{-1 \mathrm{~b})}$ & This study \\
\hline \multicolumn{5}{|l|}{ Ibuprofen (8) } \\
\hline $\begin{array}{l}\text { Microorganisms and } \\
\text { heterologous } \\
\text { expressed P450s }\end{array}$ & $9,10,11$ & - & $<30 \mathrm{mg} \mathrm{L}^{-1 \mathrm{~b})}$ & $\begin{array}{l}(41)(39) \\
(40)(25)\end{array}$ \\
\hline P450 BM3 variants ${ }^{c)}$ & 9 & - & $400 \mathrm{mg} \mathrm{L}^{-1 \mathrm{~b})}$ & $(20)$ \\
\hline M. hiemalis & $9(90 \%), \mathbf{1 0}(2 \%), \mathbf{1 1}(8 \%)$ & $4 \mathrm{~d} / 50 \mathrm{~mL}$ & $\left.990 \mathrm{mg} \mathrm{L}^{-1} \mathrm{~b}\right)$ & This study \\
\hline \multicolumn{5}{|l|}{ Mefenamic acid (12) } \\
\hline P. sordida & $\begin{array}{l}13(67 \%), \quad 14 \quad(13 \%), \quad 18 \\
17 \%), 19(3 \%)\end{array}$ & $7 \mathrm{~d} / 200 \mathrm{~mL}$ & $>3 \mathrm{mg} \mathrm{L}^{-1 \mathrm{~b})}$ & (26) \\
\hline P450 BM3 variants ${ }^{c}$ & $\begin{array}{l}\mathbf{1 3}(40 \%), \quad 20 \quad(55 \%), \quad 21 \\
(5 \%)\end{array}$ & - & $216 \mathrm{mg} \mathrm{L}^{-1 \mathrm{~b})}$ & $(18)(43)$ \\
\hline B. bassiana & $\mathbf{1 3}(68 \%), \mathbf{1 4}(32 \%)$ & $4 \mathrm{~d} / 50 \mathrm{~mL}$ & $520 \mathrm{mg} \mathrm{L}^{-1 \mathrm{~b})}$ & This study \\
\hline \multicolumn{5}{|c|}{ a) The duration of the process includes cultivation of the main culture, expression (recombinant produced P450s) and } \\
\hline
\end{tabular}

602

603 
604 TAB 2

605 Results of the proteome analysis of the biotransformations with Beauveria bassiana carried

606 out with different substrates. The numbers stand for the quantity of clearly attributable

607 peptide fragments to a protein. A higher number contributes to a higher probability that the

608 protein is actually present in the sample. A sample with glucose as substrate served as a

609 reference.

\begin{tabular}{cccc}
\hline & Glucose & Diclofenac (1) & $\begin{array}{c}(R)-2- \\
\text { phenoxypropionic } \\
\text { acid }\end{array}$ \\
\hline $\begin{array}{c}\text { NADPH-CYP- } \\
\text { Reductase } \\
\text { CYP52A10 }\end{array}$ & $\mathbf{1 4}$ & $\mathbf{9}$ & $\mathbf{1 0}$ \\
CYP52A13 & $\mathbf{2}$ & 0 & $\mathbf{1 1}$ \\
CYP548A5 & 0 & 0 & 0 \\
CYP51F1 & 0 & $\mathbf{5}$ & 0 \\
CYP684A2 & 0 & $\mathbf{1}$ & 0 \\
\hline
\end{tabular}

610

611

612

613

614

615

616

617

618

619 


\section{$620 \quad$ Figure legends}

621

\section{FIG 1}

623 Diclofenac (1) biotransformations with the filamentous fungi Beauveria bassiana,

624 Clitocybe nebularis and Mucor hiemalis. The reactions were carried out in $400 \mathrm{~mL}$ of PEG

625 broth with $0.6 \mathrm{~g} \mathrm{~L}^{-1}$ substrate for $144 \mathrm{~h}$ at $27^{\circ} \mathrm{C}$ and $180 \mathrm{rpm}$. Red: negative control without

626 cells; Magenta: standard of 4'-hydroxydiclofenac (2), 5-hydroxydiclofenac (3) and

627 5-hydroxyquinoneimine (4); Green: Beauveria bassiana; Blue: Mucor hiemalis; Ocher:

628 Clitocybe nebularis. The retention times for the different metabolites are: 11.9 min (5);

$62913.1 \min (\mathbf{4}) ; 13.3 \min (\mathbf{2}$ and 3$) ; 15.5 \min (\mathbf{1})$.

631 SCHEME 1

632 Diclofenac metabolites $(\mathbf{2}-\mathbf{5})$ synthesized by different filamentous fungi as biocatalyst 633 using $0.6 \mathrm{~g} \mathrm{~L}^{-1}$ substrate. The isolated yields after extraction and purification via semi634 preparative HPLC and the product distribution in brackets are given. The metabolites

635 4'-hydroxydiclofenac (2), 5-hydroxydiclofenac (3), 5-hydroxyquinoneimine (4),

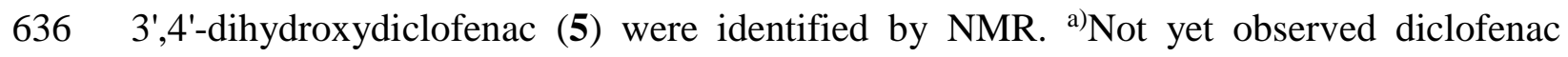
637 metabolite.

\section{SCHEME 2}

640 NSAID-metabolites synthesized by different filamentous fungi as biocatalyst using $1 \mathrm{~g} \mathrm{~L}^{-1}$

641 substrate. The isolated yields after extraction and purification via semi-preparative HPLC 642 and the product distribution in brackets are given. The metabolites 6-o-desmethylnaproxen 
643 (7), 2-hydroxyibuprofen (9), 1-hydroxyibuprofen (10), 1,2-dihydroxyibuprofen (11),

644 3'-hydroxymethylmefenamic acid (13) and 3'-carboxymefenamic acid (14) were identified

645 by NMR. ${ }^{\text {a)} P r o d u c t s ~ w e r e ~ n o t ~ p u r i f i e d ; ~ h e n c e ~ n o ~ i s o l a t e d ~ y i e l d ~ a n d ~ e x a c t ~ p r o d u c t s ~ a r e ~ g i v e n . ~}$

646 


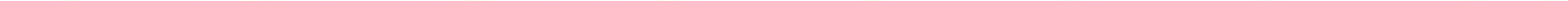



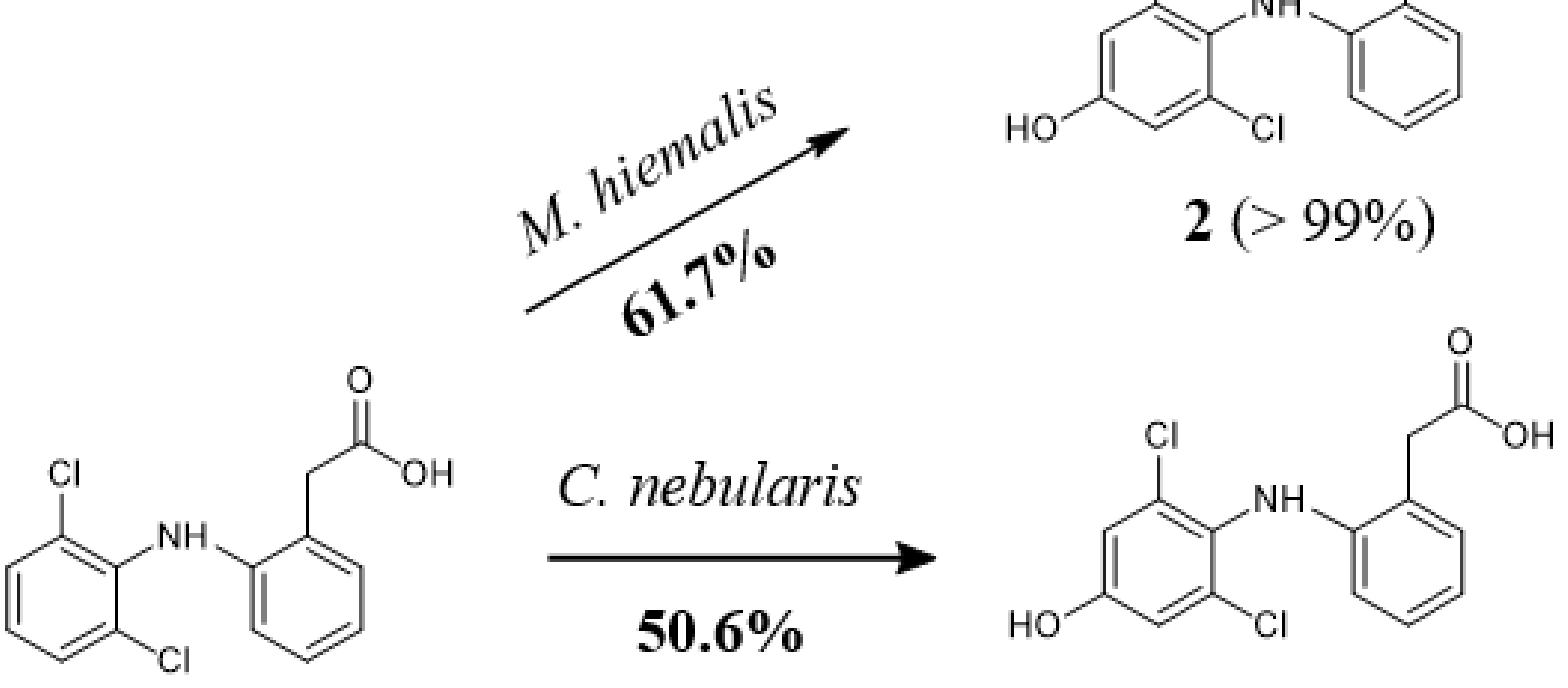

C. nebularis

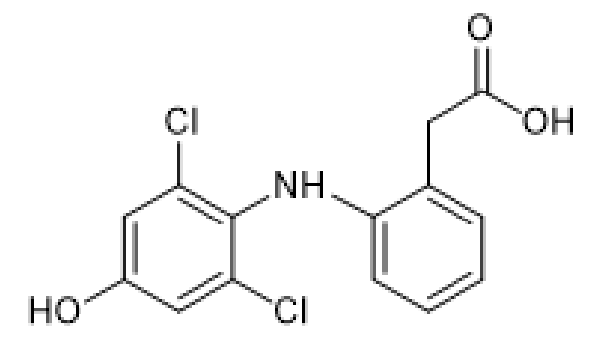<smiles>O=C(O)Cc1cc(O)ccc1Nc1c(Cl)cccc1Cl</smiles><smiles>O=C1C=CC(=Nc2c(Cl)cccc2Cl)C(CC(=O)O)=C1</smiles>

1

$2(60 \%)$

$3(30 \%)$

$4(10 \%)$
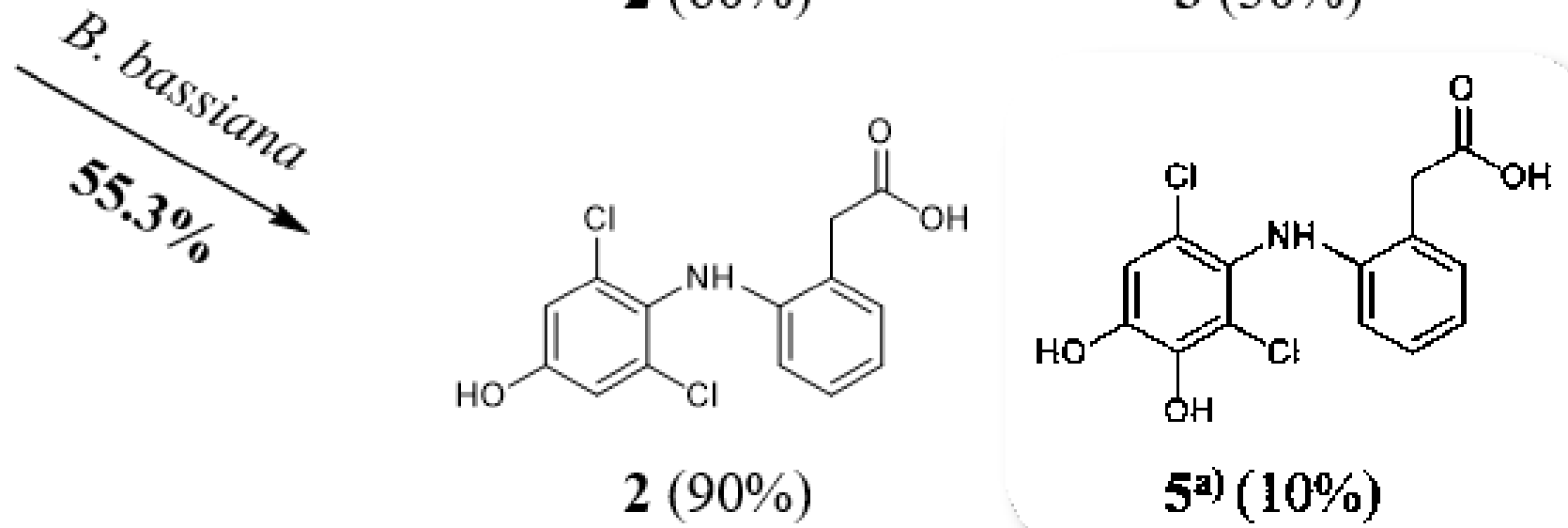
B. bassiana a)

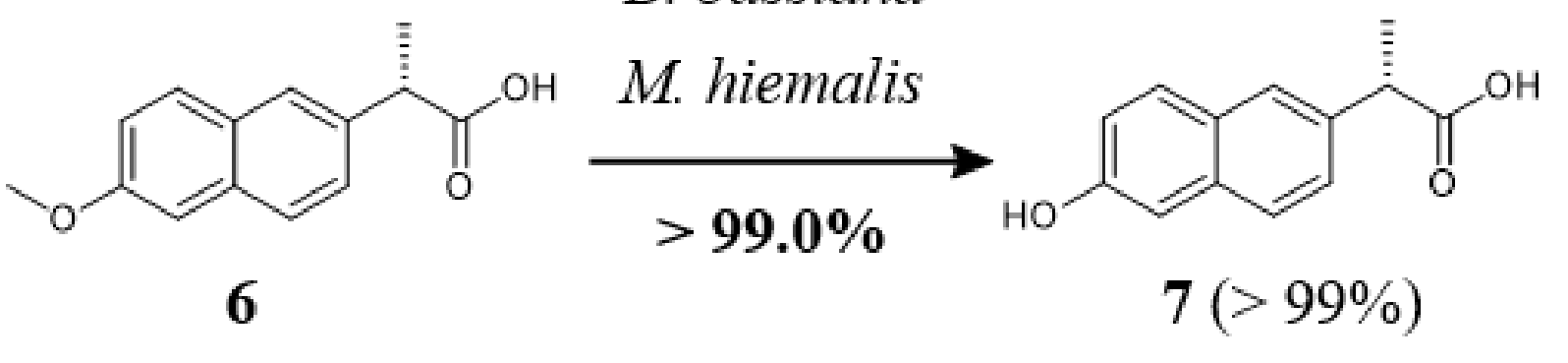

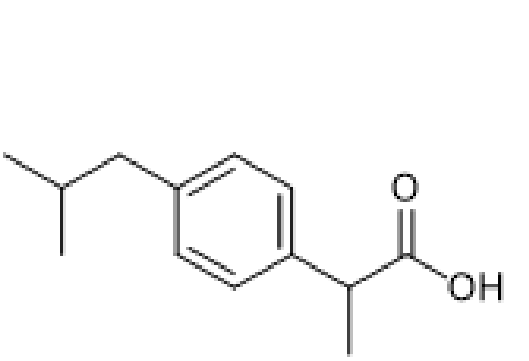

8

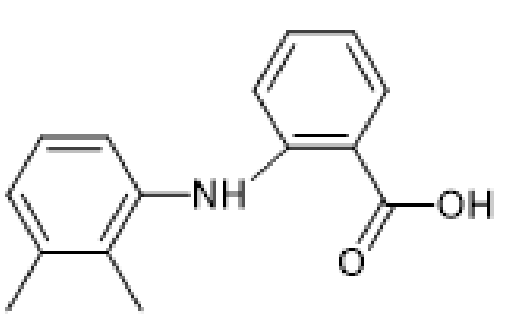

12
B. bassiana a)

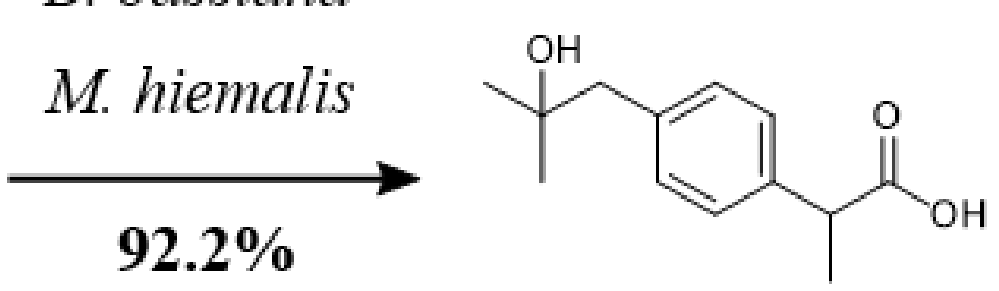

$9(90 \%)$

C. nebularis a)

B. bassiana

$48.0 \%$

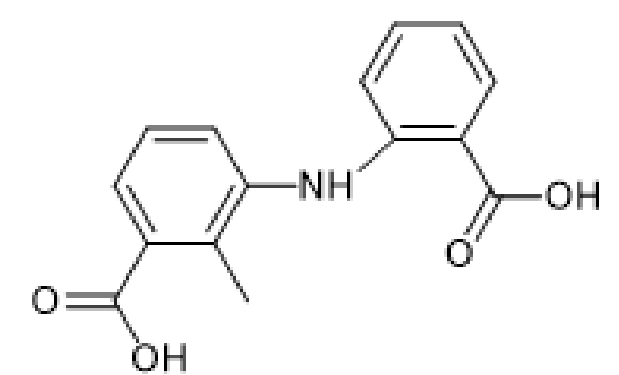

$14(32 \%)$ 